\title{
Brachydactyly type A2
}

INSERM

\section{Source}

INSERM. (1999). Orphanet: an online rare disease and orphan drug data base.

Brachydactyly type A2. ORPHA:93396

Brachydactyly type A2 (BDA2) is a congenital malformation characterized by shortening (hypoplasia or aplasia) of the middle phalanges of the index finger and, sometimes, of the little finger. 